Int.J. Hum. Soc. Dev. Res.

ISSN (P):2521-1439; ISSN (E):2523-4331

Volume 4, Number 1, 2020. 23-30

DOI:10.30546/2523-4331.2020.4.1.23

\title{
THE LLC STRATEGY RELATION WITH STUDENTS' ACHIEVEMENT IMPROVEMENT
}

\section{Dalifati ZILIWU}

Institute of Teachers Training (IKIP), Gunung Sitoli Nias, Indonesia

(C) The Author(s) 2020

\section{ABSTRACT}

Many teaching strategies could be applied by teachers in the classrooms to improve teaching learning process. This correlation research was conducted to find the $r$ - value of Lightening Leaning Climate (LLC) and students leaning achievement. A study was carried out at Junior High School (SMPN 1 Namohula Esiwa, Nias of Indonesia). It was to find the effect of the learning climate lightening strategy on increasing student activity in integrated science learning in SMPN 1 Namohalu Esiwa, then the magnitude of the correlation between variables was calculated using data from respondents using the formula $\mathrm{r}$ product moment, obtained by RXY results amounted to 0.741 . The findings of this study indicate that with the lightening the learning climate strategy, student learning activeness can be maximally increased. So, the LLC strategy has an effect on student learning activeness is equal to $54.9 \%$.

C)2020.All rights reserved

\section{ARTICLE HISTORY}

Received: 08/01/2020

Accepted: 05/04/2020

Published online: 27/04/2020

\section{KEYWORDS}

Strategy; learning achievement; Lightening Leaning Climate (LLC); Science lessons; improvement 


\section{Introduction}

Education is one of the efforts in building a very important life that is expected to be able to improve abilities, improve the quality of life, and improve the dignity of Indonesian people, to become educated and faithful people, virtuous, knowledgeable, knowledgeable, skilled, personality, responsible, participatory, innovative and creative in order to answer the challenges of the development of the times. The development of science and information technology forces a shift in conventional learning paradigms towards technology-based learning or education based technology. In conventional learning, teachers are the main source of knowledge for their students. The teacher is considered as a man who knows everything, has all the knowledge while students are human beings who need to be equipped with knowledge through the transfer of knowledge. Whatever the teacher says is true, whereas in technology-based learning, the teacher is not the only source of knowledge but only as a facilitator, motivator and evaluator.

This study aimed at applying Lightening Learning Climate (LLC) method to overcome the Indonesian pupils who have some problems in Biology, Physics and Chemistry learning. Natural science gives considerable influence in daily life and in the development of science. Science education in schools is expected to prepare students to be able to use knowledge functionally in carrying out daily life. For this reason, learning is expected to provide experience through a comfortable and pleasant learning climate. A more effective learning process needs the variation of learning strategies that comfortable and enjoyable for students. Student success is the final achievement expected by a teacher who is the target in designing the learning process. The main task of the teacher is to prepare the teaching system through the ability to prepare the administration of teaching which will be used as a guide in shaping the competencies of students (Mulyasa, 2010). To anticipate this, the teacher is expected to use methods, strategies, approaches and learning models that are more relevant to foster student learning activities that are better and more meaningful.

Initial data collection in Junior High Schools (SMP) of Nias Island of Indonesia, it was found that the teachers is more dominating the implementation of teaching and learning activities in the class. It causes students to be passive in participating in teaching and learning activities, student motivation and interest 
is still lacking due to the implementation of the teacher learning process using monotonous conventional methods and teacher-centered learning so students are less actively involved in the learning process. Students who find it difficult to understand science subject matter will make them lazy to be actively involved in learning activities. Students who still lack the completeness of learning such as textbooks will find it difficult to understand the subject matter in more depth so they tend to rely on the material that has been delivered by the teacher. Students will find it difficult to play an active role in the learning process to build and find their own knowledge through interaction with other students, so students will prefer to memorize the facts in the textbook.

The activeness of students in the learning process is the key to the success of the learning conducted by the teacher. This student activity shows the interest and desire of students to learn. Thus, Slameto (2010) argued that the activeness of students in the learning process will enliven the learning atmosphere, because according to him knowledge, skills, and attitudes cannot be transferred just like that but must go through a process that is quite long and sustainable. False learning practices will condition students as recipients of knowledge, be spoiled, and not creative in thinking and managing their own knowledge or whatever is needed to be learned. Positive student activities in learning include: students often ask the teacher or other students, their efforts in working on the assignments given by the teacher, the desire and ability of students to answer questions, or just a pleasure when given a learning task. All of these activities and behaviors are aspects in the assessment of learning, both in terms of the process and in terms of results. Student activities during the learning process will increase the intensity of interaction between the teacher and students and between students and other students. As for terms of results is the increase in students' knowledge, skills and attitudes after experiencing the learning process.

Based on the problem stated above, this study is an alternative way to increase the students' activities through the lightening the learning climate strategy. Hamruni (2012: 185) considers that the learning climate lightening strategy is one of the efforts that will be able to turn on activities and create an atmosphere of learning that is conducive, fun, comfortable, not rigid or informal and not frightening for students. The activity that occurs is to ask students to make creative humor that has to do with the material. This strategy does not only encourage students to do something, but at the same time makes students think about the subject matter. Lightening the Learning Climate (LLC) is a teaching 
strategy used by teachers to reduce the formal learning atmosphere so as to create a pleasant classroom atmosphere.

\section{Research Design}

Researchers used a correlation design to find the $r$ value of LLC in teaching Science Class in Junior High School. This study attempted to describe the indicators of research variables and interpret them based on data obtained in quantitative form using statistical science. The population in this study were all students of class VIII, amounting to 100 people with a sample selected using cluster random sampling in order to obtain students of class VIII-a, amounting to 25 people to be assigned as research respondents. This research data was collected using a questionnaire response to the learning strategy used in this study is a strategy of lightening the learning climate, amounting to 20 statements. This study also used a questionnaire of student activeness responses in the learning process which consisted of 20 statements.

\section{Findings and Discussion}

Data collected from two types of questionnaires distributed to respondents were then represented in calculation. The data of the two questionnaires showed that descriptively there was no significant difference between the two variables in this study, where for the questionnaire of the learning climate lightening strategy the average value of 62.96 with a standard deviation of 9.598 was as for the student activity questionnaire in learning known for the average value - it was 69.36 with a standard deviation of 6.164 . Before the data of these two variables are analyzed further, first the normality of the data is tested using the normality test;

\section{Tests of Normality}

Kolmogorov-Smirnova Shapiro-Wilk ; Df Statistics Sig. Df Statistics Sig.

LLC Strategy .223 25.002.897 25.015; Student Activity .169 25.064.90425 .022

a. Lilliefors Significance Correction 
Test results on normalcy data indicate that the two data are normally distributed when viewed using the Shapiro-Wilk test. Data is said to be normally distributed if the significance value $\alpha>(0.05)$ as indicated by the two results above. In testing the questionnaire data the strategy of lightening the learning climate shows that the value of $\alpha(0.15)>(0.05)$ as well as for student activeness data with a value of $\alpha(0.22)>(0.05)$ so that both data have a normal distribution.

It was to find the effect of the learning climate lightening strategy on increasing student activity in integrated science learning in class VIII-a SMP Negeri 1 Namohalu Esiwa, then the magnitude of the correlation between variables was calculated using data from respondents using the formula $\mathrm{r}$ product moment, obtained by rxy results amounted to 0.741 which is included in the high correlation. Calculation results were found in the Test results for the correlation of the two data Correlations ; LLC liveliness;

LLC Strategy Pearson Correlation $1.741 * *$; Sig. (2-tailed) .000 ;Sum of Squares and Cross-products 2.211E3 1052.360; Covariance 92,123 43,848; N 2525

\section{Liveliness}

Pearson Correlation Students .741** 1; Sig. (2-tailed) .000 ; Sum of Squares and Cross-products 1.052E3 911,760; Covariance 43,848 37,990; N 2525

**. Correlation is significant at the 0.01 level (2-tailed).

The results of the coefficient of determination obtained a percentage between the influence of the Lightening the Learning Climate strategy on increasing student activity in integrated science learning in class VIII-a State Junior High School 1 Namohalu Esiwa, it reached 54.9\%. After finishing the data processing and the results have been interpreted, then hypothesis testing is then performed. The calculation results show that the t-test value of 5.295 is greater than the table of 1.714 as shown in table 5. This means that an alternative hypothesis is accepted that there is a significant influence between the lightening the learning climate strategy on increasing student activity in integrated science learning in class VIII-a Namohalu Esiwa Middle School 1.

Result of Testing the effect of LLC strategies on student activity

Unstandardized Coefficients Model Standardized Coefficients t Sig.

B Std. Beta Error

Int. J. Hum. Soc. Dev. Res. 
1 (Constant) - 17,096 15,176-1.127.272

The liveliness of 1,154,218,741 5,295,000

a. Dependent Variable: LLC Strategy

\section{Discussion}

In this study, the main problem is whether or not there is the influence of the lightening the learning climate strategy on increasing student activity in integrated science learning in class VIII-1 of SMP Negeri 1 Namohalu Esiwa. The research instrument in the form of questionnaire was administered in the classroom. From the results of the questionnaire processing it can be seen that the lightening the learning climate strategy has a close influence on increasing student activity in integrated science learning in class VIII-a State Junior High School 1 Namohalu Esiwa. Based on the results of this study, then given the answer to the main problem that is there is a significant influence between the strategy of lightening the learning climate on increasing student activity in integrated science learning in class VIII-a State Junior High School 1 Namohalu Esiwa.

The findings of this study indicate that with the lightening the learning climate strategy, student learning activeness can be maximally increased. So, the learning climate lightening strategy has an effect on students' learning activeness is equal to $54.9 \%$. Although students' activity has increased after improving the learning climate, the absolute changes that can occur in the learning climate are quite small (Silkens et al., 2016). Therefore, it is important for teachers to create a good learning climate even for underprivileged students so that they will definitely make changes in their attitudes and results in improving their studies. Informal activities that occur are still in an effort to get students to think about the topic being studied and then be represented in student creations (Silberman, 2009: 90). The success of this strategy is based on the strengths of the learning climate lightening strategy, including: the teacher can control the sequence and passing of subject matter; can invite students to use creative humor about teaching directly; students can relax and freely express their opinions; and can be used for large numbers of students and student sizes.

Schools should also consider the comfort of their students, such as learning satisfaction, a good and conducive learning climate, and stress management rather than just the convenience of infrastructure (Shalini, 2016). It is important 
for education managers to design learning systems and joint policies so that they can produce a better learning climate than doing it in isolated conditions and the existence of uncertainty characterization which is the key problem.

The results of the study above indicate there is a positive relationship between students' attitudes towards the school climate. Students' attitudes toward teachers depend on teacher attitudes in the classroom and their dedication to teaching methods (Senturk \& Mutlu, 2019). Hetland et al., (2011) emphasized the role of leadership in the division of tasks and their closeness to factors in task management such as a sense of team support, time for learning, learning autonomy, and opportunities to develop themselves. Students' expectations of a learning climate that is safe, comfortable and conducive are related to the ability of teachers to establish relationships among fellow citizens of learning, the learning process and the physical characteristics of the learning environment itself (Haidari \& Karakus, 2020).

Learning with the lightening the learning climate strategy can arouse curiosity and cooperation among students and can create a pleasant atmosphere because it can enhance collaboration in groups (Safitri et al., 2014). Besides being able to increase student activity in learning, the lightening the learning climate strategy can also increase student creativity because students can be more active and creative in looking for answers on their own or in presenting results so as to make them active and recall the material that has been described (Hapsan \& Kristiawati, 2019 ). This requires serious efforts, both in policy and practice policy to build a learning climate in fostering students' thinking and curiosity (Maksum \& Khory, 2020).

\section{Conclusions}

It is concluded that the learning climate, thinking patterns, and curiosity play important roles in students' academic performance. Thus, the quality of students can be improved if the curiosity of these students is cultivated so that they are able to form reflective thinking patterns. The results of this study indicate that the lightening the learning climate strategy increased students' activity in learning by $54.9 \%$ which is considered quite good if it can be applied sustainably.

\section{Disclosure statement}

No potential conflict of interest was reported by the author. 


\section{References and notes:}

Amran Hapsan, A., \& Kristiawati. (2019). Pengaruh Metode Lightening The Learning Climate Terhadap Kreatifitas dan Kemampuan Berpikir Siswa. Jurnal Analisa, 5 (2):pp.171-179.

Haidari, S.M., \& Karakus, F. (2020). Teacher and Student Perspectives on Safe Learning Climate in Gifted Education. Journal of Theoretical Educational Science, 13(2), 311-333, April 2020

Hamruni. (2012). Strategi Pembelajaran. Yogyakarta: Insan Madani.

Hetland, H., Skogstad, A., Hetland, J., \& Mikkelsen, A. (2011). Leadership and Learning Climate in a Work Setting. European Psychologist, DOI: 10.1027/10169040/a000037

Khalid.M. (2019).Using group work in Teaching writing skill. International Journal of Humanities and Social Development Research,DOI: 10.30546/25234331.2019.3.2.41. Azerbaijan, Baku. Volume 3, № 2, 2019,pp. 41-49.

Maksum, A., \& Khory, F.D. (2020). Effect of Learning Climate, Thinking Pattern, and Curiosity on Academic Performance in Higher Education. Problems of Education in the 21st Century, 78 (1).

Mulyasa, E. (2010). Kurikulum Tingkat Satuan Pendidikan: Sebuah Panduan Praktis. Bandung: Remaja Rosdakarya.

Safitri, H., Saptaningrum, E., \& Siswanto, J. (2014). Pengaruh Strategi Pembelajaran Lightening the Learning Climate pada Materi Teori Kinetik Gas Terhadap Hasil Belajar Siswa di SMA Negeri 1 Jepara. Jurnal Penelitian Pembelajaran Fisika, 5 (2).

Sentürk, H.E., \& Mutlu, T.O. (2019). An Investigation on Learning Climate at Sport High Schools. Journal of Education and Training Studies, 7 (9), September 2019.

Shalini, P.S. (2016). An Analysis of Learning Climate as Determinant of Academic Achievement. International Journal of Advanced Research, 4 (4), pp.934-938

Silberman, M. (2009). Active Learning: 101 Strategi Pembelajaran Aktif. Yogyakarta: Insan Madani.

Silkens, M.E.W.M., Arah, O.A., Scherpbier, A.J.J.A., Heineman, M.J., \& Lombarts, K.M.J.M.H. (2016). Focus on Quality: Investigating Residents' Learning Climate Perceptions. Public Library of Science One, 11 (1), doi:10.1371/journal.pone.0147108

Slameto. (2010). Belajar dan faktor-faktor yang mempengaruhinya. Jakarta: Rineka Cipta

Contact Information.

Email address: dalifati@gmail.com 